
and Aromatic Plants

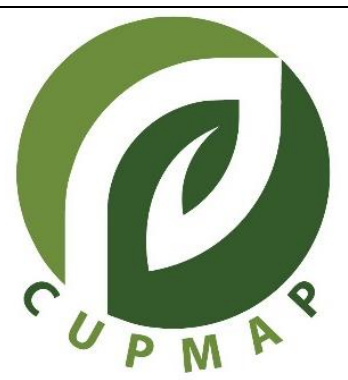

\title{
Comparative Cytotoxic Effects of the Hydrosols of some Ethnobotanic Plants
}

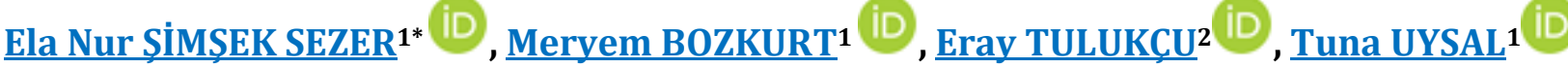

\author{
${ }^{1}$ Selçuk University, Science Faculty, Biology Department, Konya, TURKEY \\ ${ }^{2}$ Selçuk University, Çumra Vocational High School, Medicinal Plant Program, Konya, TURKEY \\ *Corresponding author : simsekelaa@gmail.com
}

https://doi.org/10.38093/cupmap.765089

Received : 06/07/2020 Accepted : 08/12/2020

\begin{abstract}
Hydrosols are aqueous solutions and by-products of the essential oil distillation procedure. They have many medicinal benefits because contain the water-soluble components, vitamins and minerals of the plant that has been distilled. On the other hand, colorectal cancer (CRC) is the third most common cancer in both men and women worldwide and is the main cause of death in gastrointestinal cancer. Hence in this study, the cytotoxic effects of hydrosols obtained from five different ethnobotanical plants (Melissa officinalis L., Achillea teretifolia Willd, Achillea aleppica subsp. zederbaueri (Hayek) Hub.-Mor., Origanum onites and Salvia fruticosa Mill have been investigated on the colorectal cancer cell line. For the determination of the hydrosols cytotoxic effect MTT assay was used. MTT (3-(4,5-dimethylthiazol-2-yl)-2,5-diphenyltetrazolium bromide) is used to determine the cytotoxic or cytostatic effects of plant extracts, potential medicinal agents and toxic materials. Based on the results of the cytotoxicity assay, the most effective extract was obtained from Origanum onites and the next effective extract from Melissa officinalis. On the other hand, both Achillea extracts showed low cytotoxic activity. Consequently, this study provides some criticism on the potentials of some plants traditionally used as an anticancer agent, and also shows that there is more need to investigate the cause of cell death and active substances.
\end{abstract}

Key Words: Cytotoxicity, Hydrosols, Lemon balm, Turkish oregano, CRC.

(c) CUPMAP. All rights reserved.

\section{Introduction}

Ethnobotanical researches contribute significantly to the scientific evaluation of plants with their content, which has been acquired through trial and error and reflects valuable information that has been passed down from generation to generation as a result of a long period of time (Kendir \& Güvenç 2010). Our country, which has a rich cultural heritage, also has an extensive ethnobotanical information treasure. The use of plants as complementary medicine for cancer, especially in difficult cancer types, has recently increased.

Cancer is an important public health problem and causes serious pain and economic losses worldwide. Colorectal cancer is the third most common cancer in the world. Therefore, more research is needed to develop safe products for the prevention and treatment of all human cancers. Approximately $60 \%$ of the drugs currently used for cancer treatment have been isolated from natural products (Gordaliza, 2009), and the plant kingdom 
has been the primary source. Wild sources of medicinal plants have been used by humans for centuries in traditional healing systems. Indigenous people have adopted different forms of application and use to take advantage of this natural resource (Adnan et al., 2014).

Melissa officinalis L. (Lamiaceae) is one of the most used medicinal plants in Europe and the Mediterranean region, as a herbal tea for their aromatic, digestive and antispasmodic properties in nervous disturbance of sleep and functional gastrointestinal disorders (Bisset, 1994). Achillea L. (civanperçemi; Turkish name) is a medicinal plant genus which has been used since ancient times. It possesses diversity all around the world. The majority of the Achillea species are important native economic plants of Anatolia. In Turkey, herbal teas prepared from some Achillea species are used in folk medicine for abdominal pain, diarrhea, and flatulence as well as a diuretic and emmenagog. Some investigations about anti-oxidant and cytotoxic effects of Achillea species have been performed. The extracts or essential oils of Achillea wilhelmsii C. Koch, $A$. micrantha Willd., $A$. millefolium L., $A$. pannonica Scheele and A. fragrantissima (Forssk.) Sch. Bip. has been reported to be natural antioxidant sources (Souri et al., 2004; Nickavar et al., 2006; Wojdylo et al., 2007; Bozin et al., 2008; Tarawneh et al., 2010). Also, Achillea millefolium L., $A$. clavennae L., $A$. talagonica Bioss., $A$. wilhelmsii C. Koch and A. fragrantissima are important species with cytotoxic effects (Sathiyamoorthy et al., 1999; Trifunovic et al., 2006; Saeidnia et al., 2009; Ali et al., 2011; Li et al. 2011; Bali et al. 2015; Amini Navaie et al., 2015; Köngül et al., 2017). Origanum onites L., known as Turkish oregano, is a traditional and medicinal herb. Infusions obtained from aerial parts are effective in the treatment of several gastrointestinal diseases, influenza, bronchitis, hypertension, diabetes, high cholesterol, stomach disorders and leukaemia (Sivas and Tomsuk 2011; Sargin et al., 2013; Gürdal \& Kültür 2013). Salvia fruticosa, insufficiently studied for various activities, is a Mediterranean medicinal and aromatic herb. It is known for its antioxidant, antimicrobial and antiproliferative activities (Alimpic et al., 2015; Altay \& Bozoğlu 2017). Essential oils are usually extracted from plants by steam distillation, where an aqueous phase called hydrosol is obtained. Unlike essential oils, hydrosol studies are limited, despite the interest of the food, cosmetic and phytotherapeutic industries to find a natural protective alternative (Tornuk et al., 2011; Hamedi et al., 2017). Hydrosol is highly valuable as it contains all the water-soluble substances of the plant.

The present study was designed to investigate cytotoxic effects of the hydrosols of five ethno-botanic plants (Melissa officinalis L., Achillea teretifolia Willd, Achillea aleppica subsp. zederbaueri (Hayek) Hub.-Mor., Origanum onites and Salvia fruticosa Mill.) on the colorectal cell line.

\section{Material and Method}

\subsection{Plant material}

In our study, investigated plant samples were provided from Eray TULUKÇU. Plant samples were grown at Selcuk University, Çumra Vocational School, Medical and Aromatic Plants Department. Hydrosol preparations were performed the protocol of Linskens (1997). The hydrosols were kept in refrigerated at $4^{\circ} \mathrm{C}$ until they are used. The extracts coded as Melissa officinalis (MOE) Achillea teretifolia (ATE), Achillea aleppica subsp. zederbaueri (AAE), Origanum onites (ORE) and Salvia fruticosa (SFE), respectively.

\subsection{Cell lines}

Human colon adenocarcinoma cells, DLD1 was obtained from ATCC and they were cultured in $10 \%(\mathrm{v} / \mathrm{v})$ heat-inactivated fetal 
bovine serum (FBS), $1 \%(\mathrm{v} / \mathrm{v})$ penicillinstreptomycin supplemented RPMI 1640 medium. Cells were incubated at $37^{\circ} \mathrm{C}$ under $5 \% \quad \mathrm{CO}_{2}$ conditions. After reaching 70\% confluency, the cells were trypsinized, counted and transferred in 96-well plates.

\subsection{Cytotoxicity assays}

The cytotoxic activity of the hydrosols was tested on the DLD1 cell line. Hydrosols were prepared in six different dilutions (v/v) and were applied to the cells. Different amounts of the hydrosol were prepared for cell treatment by diluting the stock with medium only. Then the plates were incubated for 24 48 hours. The cell proliferation assay was carried out via MTT $(5 \mathrm{mg} / \mathrm{ml})$. The optical density of the plates was measured using the Elisa microplate reader at $540 \mathrm{~nm}$. Each experiment was performed three times and the mean values were taken into consideration.

\subsection{Statistical Analysis}

For statistical analysis of the data, multiple comparisons were made using one-way variance analysis (ANOVA) followed by Dunnett's test for post hoc analysis. The differences in $\mathrm{p}<0.05, \mathrm{p}<0.01$ and $\mathrm{p}<0.001$ were considered statistically significant.

\section{Results and Discussion}

As a result of the link between man and plant that has been going on for centuries, the ethnobotanical discipline, which is considered important all over the world, was born. Ethnobotanical research contributes to the scientific evaluation of plants by providing valuable information obtained through experimentation and passed down from generation to generation. The use of medicinal plants for thousands of years has played a major role in the emergence of ethnobotany for the treatment of various diseases such as cancer. By the World Health Organization (WHO) data (WHO, 2001), 80\% of the world population prefer herbal medicines in the treatment of various diseases (Chikezie \& Ojiako, 2015; Msomi and Simelane, 2018; Nguyen et al., 2020; Khan et al., 2020). With this situation, ethnobotanical knowledge transferred from the early ages comes to the fore and the use of medicinal plants becomes important (Bozyel \& Merdamert, 2018). Turkey, which has hosted many civilizations, constitutes a rich cultural heritage and rich research environment in terms of ethnobotanical studies. Medicinal plants are vital sources of readily accessible remedy used in the countryside healthcare system. Since cancer is a leading cause of death, various researches are carried out in this field every day worldwide. These studies usually involve investigating the effects of biologically active substances on cancer cells and are often derived from plants (Mukherjee et al. 2001). There is a great need to examine the sources of safe and inexhaustible natural substances. It is also important to understand the mechanisms of anticancer agents for future application in cancer treatment (Half et al. 2009). Increasing evidence suggests that extracts and/or active ingredients from plants are effective against cancer by preventing carcinogenesis and tumour progression or by killing cancer cells (Demir et al., 2020).

Although the cytotoxic effects of the plants preferred in our study have been previously examined in the several cell lines such as colon, breast, prostate and liver cell lines. As far as we know our study is a first in terms of the cell line used in our study. This is the first study to reveal the cytotoxic effect of hydrosols from various ethnobotanical plants on colorectal cancer cell line DLD1. According to the cytotoxicity test for cells treated by Melissa officinalis, Achillea teretifolia, Achillea aleppica subsp zederbaueri, Origanum onites and Salvia fruticosa aqueous extracts, our results show that the cytotoxicity for the DLD1 cell line 
between the applied dose ranges. From the results of MTT, the most effective extract is Origanum onites. On the other hand, two Achillea extracts exhibited less cytotoxic effects than others in the doses and time intervals administered. The concentration of $50 \%$ cellular cytotoxicity of extracts on cancer cells $\left(\mathrm{IC}_{50}\right.$ ) was based on 48-hour absorbance values (Chen et al., 2009). The
$\mathrm{IC}_{50}$ dose is approximately $25 \%$ for Melissa officinalis (MOE), 25\% for Origanum onites (ORE) and $50 \%$ for Salvia fruticosa (SFE). The cytotoxicity graphs of 24-48h treatments were given Figure 1 and Figure 2. Different solvents and extraction methods can be tried to determine the cytotoxic effects of Achillea extracts.

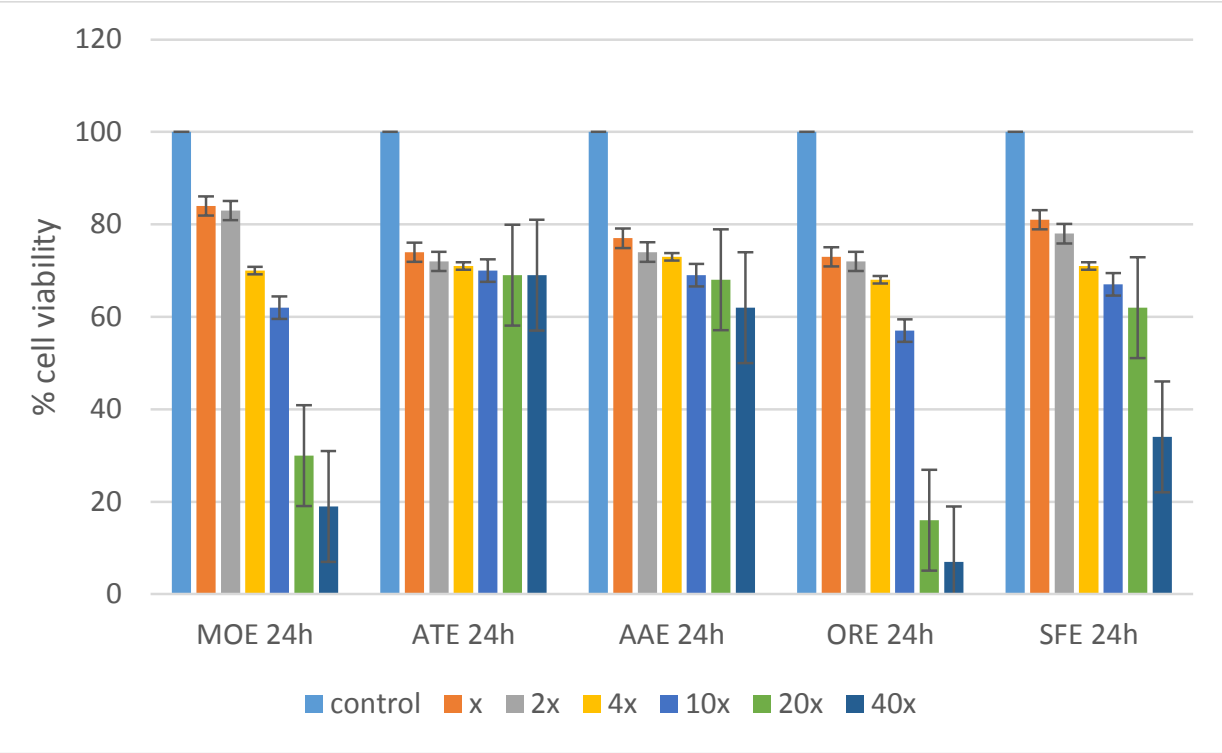

Fig.1. Graph of MTT assay after 24h treatment (40x: direct, 20x: 1/2 (v/v), 10x: 1/4 (v/v), 4x: $1 / 10(\mathrm{v} / \mathrm{v}) 2 \mathrm{x}: 1 / 20(\mathrm{v} / \mathrm{v}) \mathrm{x}: 1 / 40(\mathrm{v} / \mathrm{v}))$

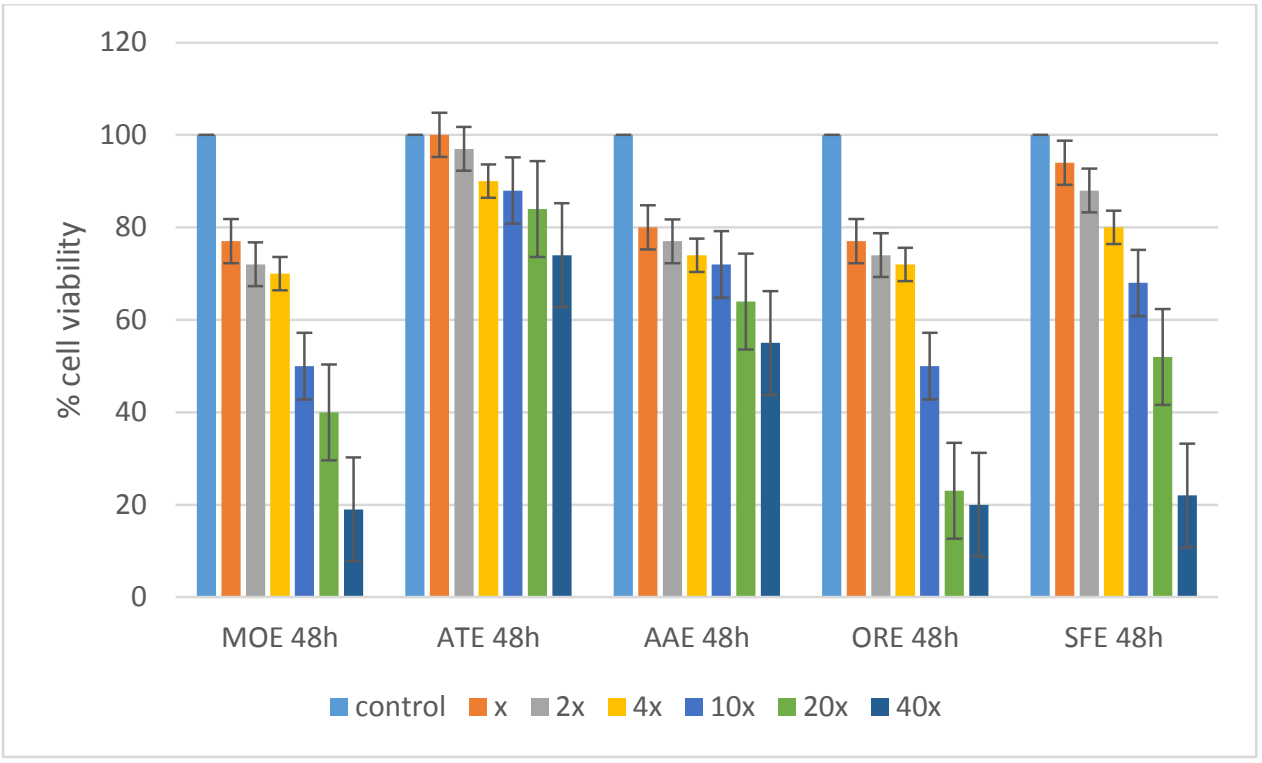

Fig. 2. Graph of MTT assay after 48h treatment (40x: 1, 20x: 1/2 (v/v), 10x: 1/4 (v/v), 4x: 1/10 (v/v) 2x:1/20(v/v) x: $1 / 40(\mathrm{v} / \mathrm{v}))$ 
Colorectal cancer is the second most frequently diagnosed in women, the third in men and fourth cancer worldwide (Jemal et al., 2011). Colorectal cancer, which is reported to cause death in approximately $60 \%$ of cases, is common in developed countries (Ferlay et al., 2015; Merika et al., 2015). Herbal extracts or preparations inhibit colorectal cancer cells by stimulating apoptosis or autophagy, inducing the cell cycle and triggering signal pathways. There are many studies on the cytotoxic and apoptotic effects of plants used in our study on various colon cancer cell lines, but as far as we know, no previous studies have been performed on the DLD1 cell line. The ethanolic and aqueous extracts from Melissa officinalis have been reported to have cytotoxic effects on human colon cancer cell line HCT-116 (Encalada et al., 2011). The hydroalcoholic extract from Melissa officinalis has been reported to inhibit apoptosis and cell proliferation in HT29 and T84 colon cancer cells (Weidner et al., 2015). In another study, it was reported that essential oil of Origanum and main component planned carvacrol has cytotoxic and apoptotic activity on Hep-G2 cells and can be evaluated as potential anticancer agents (Sivas and Tomsuk 2011). Xavier et al. (2009) have been reported that Salvia fruticosa and Salvia officinalis water extracts and their main phenolic compound rosmarinic acid has antiproliferative and pro-apoptotic effects on two human colon cancer cell lines, HCT15 and C0115.

\section{Conclusion}

In conclusion, this study gives some criticism on the potentials of some plants traditionally used in the field of pharmacology as an anticancer agent. This is a preliminary study and, in the future, it is aimed to find out the molecular mechanisms that cause cell death. Additionally, it is planned to prepare various extracts by using new solvents and different extraction techniques with the plants used in the study and investigate their cytotoxic potential.

\section{Acknowledgments}

\section{Conflict of Interest}

No conflict of interest was reported by the authors.

\section{References}

1. Adnan, M., Ullah, I., Tariq, A., Murad, W., Azizullah, A., Khan, A., Ali, N., 2014. Ethnomedicine use in the war affected region of Northwest Pakistan. J Ethnobiol Ethnomed 10: 16.

2. Ali, N., Shah, S.W., Shah, I., Ahmed, G., Ghias, M., Khan, I., 2011. Cytotoxic and anthelmintic potential of crude saponins isolated from Achillea wilhelmsii C. Koch and Teucrium stocksianum Boiss. BMC Complement Altern Med. 11:106.

3. Alimpic, A. Z., Kotur, N., Stanković, B., Marin, P. D., Matevski, V., Al Sheef, N., \& Duletić-Laušević, S. 2015. The in vitro antioxidative and cytotoxic effects of selected Salvia species water extracts. Journal of Applied Botany and Food Quality, 88(1).

4. Altay, A., \& Bozoğlu, F., 2017. Salvia fruticosa modulates mRNA expressions and activity levels of xenobiotic metabolizing CYP1A2, CYP2E1, NQ01, GPx, and GST enzymes in human colorectal adenocarcinoma HT-29 cells. Nutrition and cancer, 69(6), 892-903.

5. Amini Navaie, B., Kavoosian, S., Fattahi, S., HajianTilaki, K., Asouri, M., Bishekolaie, R., \& AkhavanNiaki, H., 2015. Antioxidant and cytotoxic effect of aqueous and hydroalcoholic extracts of the Achillea millefolium L. on MCF-7 breast cancer cell line. International Biological and Biomedical Journal, 1(3), 119-125.

6. Bisset, N.G., 1994. Herbal Drugs and Phytopharmaceuticals: A handbook for practice scientific basis (1st ed.). Stuttgart, Germany: Medpharm GmbH Scientifiv Publisher.

7. Bozin, B., Mimica-Dukic, N., Bogavac, M., Suvajdzic, L., Simin, N., Samojlik, I., \& Couladis, M., 2008. Chemical composition, antioxidant and antibacterial properties of Achillea collina Becker ex Heimerl sl and A. pannonica Scheele essential oils. Molecules, 13(9), 2058-2068.

8. Bozyel, M. E., \& Merdamert, E., 2018. Antiurolithiatic activity of medicinal plants in turkey. Science, ecology and engineering research in the globalizing world, 152.

9. Chikezie, P. C., \& Ojiako, O. A., 2015. Herbal medicine: yesterday, today and tomorrow. Alternative \& Integrative Medicine. 
10.Demir, S., Demir, E. A., \& Aliyazıcıoğlu, Y., 2020. Selective Cytotoxic Effect of Astaxanthin on Human Lung and Colon Cancer Cells. Kahramanmaraş Sütçü İmam Üniversitesi Tarım ve Doğa Dergisi, 23(6), 1489-1494.

11.Bali, E. B., Açık, L., Elçi, P., Sarper, M., Avcu, F., \& Vural, M., 2015. In vitro anti-oxidant, cytotoxic and pro-apoptotic effects of Achillea teretifolia Willd extracts on human prostate cancer cell lines. Pharmacognosy magazine, 11(Suppl 2), S308.

12.Encalada, M. A., Hoyos, K. M., Rehecho, S., Berasategi, I., de Ciriano, M. G. Í., Ansorena, D., ... \& Calvo, M. I. 2011. Anti-proliferative effect of Melissa officinalis on human colon cancer cell line. Plant Foods for Human Nutrition, 66(4), 328-334.

13. Ferlay, J., Shin, H. R., Bray, F., Forman, D., Mathers, C., \& Parkin, D. M., 2010. Estimates of worldwide burden of cancer in 2008: GLOBOCAN 2008. International journal of cancer, 127(12), 28932917.

14.Gordaliza M., 2009. Natural products as leads to anticancer drugs. Clin Transl Oncol 9:767-776.

15.Gürdal, B., \& Kültür, Ş., 2013. An ethnobotanical study of medicinal plants in Marmaris (Muğla, Turkey). Journal of Ethnopharmacology, 146(1), 113-126.

16. Half, E., Arber, N., 2009. Colon cancer: Preventive agents and the present status of chemoprevention. Exp. Opin. Pharmacother. 10: 211-219.

17.Hamedi, A., Afifi, M., \& Etemadfard, H., 2017. Investigating chemical composition and indications of hydrosol soft drinks (aromatic waters) used in Persian folk medicine for women's hormonal and reproductive health conditions. Journal of evidence-based complementary \& alternative medicine, 22(4), 824-839.

18.Jemal, A., Bray, F., Center, M.M., Ward, E., Forman, D., 2011. Global cancer statistics. Cancer J Clin. 61(2): 69-90.

19.Kendir, G., \& Güvenç, A. 2010. Etnobotanik ve Türkiye'de yapılmış etnobotanik çalışmalara genel bir bakış. Hacettepe Üniversitesi Eczacılık Fakültesi Dergisi, (1), 49-80.

20.Khan, T., Ali, M., Khan, A., Nisar, P., Jan, S. A., Afridi, S., \& Shinwari, Z. K., 2020. Anticancer Plants: A Review of the Active Phytochemicals, Applications in Animal Models, and Regulatory Aspects. Biomolecules, 10(1), 47.

21. Köngül, E., Taş, Ö., Paşayeva, L., \& Karatoprak, G. Ş., 2017. Analysis of the Cytotoxic Effects of Achillea millefolium L. Extracts on MCF7 Cell Line. Multidisciplinary Digital Publishing Institute Proceedings, 1(10), 1077.

22.Li, Y., Zhang, M. L., Cong, B., Wang, S. M., Dong, M., Sauriol, F., ... \& Kiyota, H., 2011. Achillinin A, a cytotoxic guaianolide from the flower of Yarrow, Achillea millefolium. Bioscience, biotechnology, and biochemistry, 1107062554-1107062554.
23. Linskens, H. F., \& Jackson, J. F. (Eds.). 1997. Plant volatile analysis. Berlin: Springer.

24. Merika, E., Saif, M. W., Katz, A., Syrigos, C., \& Morse, M. 2010. Colon cancer vaccines: an update. In vivo, 24(5), 607-628.

25. Msomi, N. Z., \& Simelane, M. B., 2018. Herbal Medicine. In Herbal Medicine. IntechOpen.

26. Mukherjee, A. K., Basu, S., Sarkar, N., \& Ghosh, A. C., 2001. Advances in cancer therapy with plant based natural products. Current medicinal chemistry, 8(12), 1467-1486.

27. Nguyen, N. H., Ta, Q. T. H., Pham, Q. T., Luong, T. N. H., Phung, V. T., Duong, T. H., \& Vo, V. G. 2020. Anticancer activity of novel plant extracts and compounds from adenosma bracteosum (bonati) in human lung and liver cancer cells. Molecules, 25(12), 2912.

28. Nickavar, B., Kamalinejad, M., Haj-Yahya, M., \& Shafaghi, B., 2006. Comparison of the free radical scavenging activity of six Iranian Achillea. species. Pharmaceutical biology, 44(3), 208-212.

29. Saeidnia, S., Moradi-Afrapoli, F., Gohari, A.R., Malmir, M., 2009. Cytotoxic flavonoid from Achillea talagonica Bioss. J Med Plants Res 8: 526.

30. Sathiyamoorthy, P., Lugasi-Evgi, H., Schlesinger, P., Kedar, I., Gopas, J., Pollack, Y., \& Golan-Goldhirsh, A., 1999. Screening for cytotoxic and antimalarial activities in desert plants of the Negev and Bedouin market plant products. Pharmaceutical biology, 37(3), 188-195.

31. Shinwari, Z.K., 2010. Medicinal plants research in Pakistan. J Med Plants Res 4: 161-176.

32. Sivas, H., \& Tomsuk, Ö., 2011. Antiproliferative and apoptotic effects of the essential oil of Origanum onites and carvacrol on Hep-G2 cells. Anadolu University Journal of Science And Technology, 1: (2) 171-180.

33. Souri, E., Amin, G., Dehmobed-Sharifabadi, A., Nazifi, A., \& Farsam, H., 2010. Antioxidative activity of sixty plants from Iran. Iranian Journal of Pharmaceutical Research, (1), 55-59.

34. Tarawneh, K.A., Irshaid, F., Jaran, A.S., Ezealarab. M., Khleifat, K.M., 2010. Evaluation of antibacterial and anti-oxidant activities of methanolic extracts of some medicinal plants in northern part of Jordan. J Biol Sci 10: 32532.

35. Tornuk, F., Cankurt, H., Ozturk, I., Sagdic, O., Bayram, O., \& Yetim, H., 2011. Efficacy of various plant hydrosols as natural food sanitizers in reducing Escherichia coli 0157: H7 and Salmonella Typhimurium on fresh cut carrots and apples. International Journal of Food Microbiology, 148(1), 30-35.

36. Trifunovic, S., Vajs, V., Juranić, Z., Žižak, Ž., Tešević, V., Macura, S., \& Milosavljević, S., 2006. Cytotoxic constituents of Achillea clavennae from Montenegro. Phytochemistry, 67(9), 887-893. 
37.Weidner, C., Rousseau, M., Plauth, A., Wowro, S. J., Fischer, C., Abdel-Aziz, H., \& Sauer, S., 2015. Melissa officinalis extract induces apoptosis and inhibits proliferation in colon cancer cells through formation of reactive oxygen species. Phytomedicine, 22(2), 262-270.

38.Wojdylo, A., Oszmianski, J., Czemerys, R., 2007. Anti-oxidant activity and phenolic compounds in 32 selected herbs. Food Chem 105:940 9.

39.World Health Organization. World Health Organization. [Online].; 2010. Available from: http://www.who.int/cancer/detection/colorectal cancer/en/

40.Xavier, C. P., Lima, C. F., Fernandes-Ferreira, M., \& Pereira-Wilson, C. 2009. Salvia fruticosa, Salvia officinalis, and rosmarinic acid induce apoptosis and inhibit proliferation of human colorectal cell lines: the role in MAPK/ERK pathway. Nutrition and cancer, 61(4), 564-571. 